\title{
Distribution and status of marine invasive species in and bordering the West Coast National Park
}

\author{
T.B. Robinson, C.L. Griffiths and N. Kruger
}

Robinson, T.B., C.L. Griffiths and N. Kruger. 2004. Distribution and status of marine invasive species in and bordering the West Coast National Park. Koedoe 47(1): 79-87. Pretoria. ISSN 0075-6458.

This study describes the present distribution and abundance of alien marine species within the West Coast National Park. The Mediterranean mussel Mytilus galloprovincialis was recorded in $79 \%$ of sampling areas that provided suitable rocky-shore habitat. The highest biomass $\left(25.4 \pm 18.7 \mathrm{~kg} / \mathrm{m}^{2}\right)$ was recorded in the mid-shore on Marcus Island, and total intertidal biomass in the Langebaan/Saldanha system was estimated at 281.6 tons. Including farmed and subtidal stocks, the area supports 4362 tons M. galloprovincialis in summer and 959 tons in winter. No live individuals of the European shore crab Carcinus maenas were recorded, but a single dead carapace was found. The European periwinkle Littorina saxatilis had a limited distribution within Langebaan Lagoon and supported a total population of 2.4 million individuals. The alien anemone Sagartia ornata was recorded as locally abundant (up to $426 \pm 81$ individuals $/ \mathrm{m}^{2}$ ) and was also restricted in distribution. Despite the extensive invasion of the Saldanha Bay-Langebaan Lagoon system by M. galloprovincialis, the threat to the West Coast National Park appears to be limited by low wave action and low nutrient supply to the rocky shores within the park. Although not present in detectable numbers, $C$. maenas poses a major threat to the park, should it become established there. The threats posed by $L$. saxatilis and $S$. ornata are presently unquantified but appear slight.

Key words: West Coast National Park, marine alien species, Mytilus galloprovincialis, Carcinus maenas, Littorina saxatilis, Sagartia ornata.

T.B. Robinson, C.L. Griffiths and N. Kruger, Zoology Department and Marine Biology Research Institute, University of Cape Town, Rondebosch, 7700 Republic of South Africa.

\section{Introduction}

On a global scale, species are constantly being moved from their areas of origin to new locales. Such range extensions can occur naturally, but are frequently aided (intentionally or non-intentionally) by humans (Mack et al. 2000). As a result, the marked world-wide increase in animal, plant, and microbial immigrations, has been found to roughly track the increase in human commerce (Mack et al. 2000). The principal vectors of human-mediated marine invasions are ballast water (Williams et al. 1988), mariculture (Minchin 1996), sediment held in ballast tanks (Carlton 1985), and ship hull fouling (Minchin 1996).
As South Africa's second largest bulk port (Unit for Maritime Studies 2000), the port of Saldanha faces an elevated risk of inoculation by alien species. This, in combination with the increasing rate at which invasions are occurring globally, and the threats posed by marine invasive species (Berman et al. 1992; Griffiths et al. 1992; Grosholz \& Ruiz 1996; Carlton 1996), has led to concerns regarding the protection of indigenous fauna of areas surrounding the port. These concerns have been heightened by the location of the port within Saldanha Bay and Langebaan Lagoon, parts of which form the West Coast National Park (WCNP). Established in 1985, the WCNP is the only major marine reserve 
along the west coast of South Africa. The park includes Langebaan Lagoon, Jutten, Malgas and Marcus islands and an extensive terrestrial area surrounding most of the lagoon. The lagoon itself supports a high diversity of marine taxa (Day 1959), while the surrounding sand flats and salt marshes host numerous species of palaearctic migrant waders during the southern summer (Summers et al. 1977). The lagoon is recognised under both the Ramsar and Bonn conventions and, as such, holds the status of a wetland of international importance.

Of the 17 introduced marine species recorded in South Africa by Griffiths (2000), nine are listed to have occurred, or to presently occur, within Saldanha Bay. They are the bivalves Tapes philippinarum and Mytilus galloprovincialis, the gastropods Haliotis

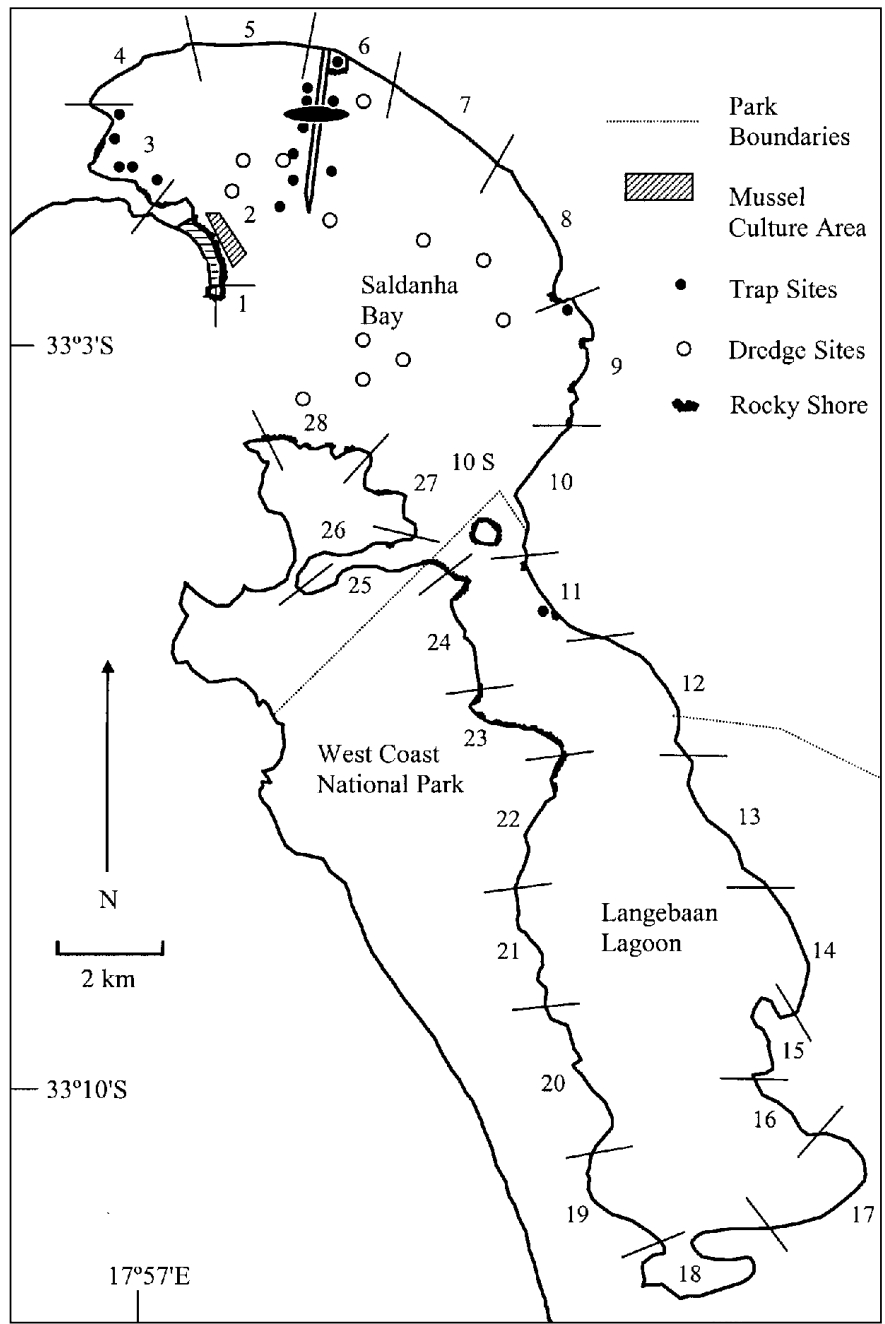

Fig. 1. Map of Saldanha Bay and Langebaan Lagoon, showing the boundaries of the West Coast National Park and the 28 areas which were sampled. 
rufescenens and Littorina saxatilis, the crabs Pilumnus hirsutus and Carcinus maenas, and the ascidians Diplosoma listerianum, Ciona intestinalis and Ascidiella aspersa. Of these, T. philippinarum and $H$. rufescenens populations have become extinct, while $D$. listerianum, $C$. intestinalis and A. aspersa are restricted to harbour environments. The introduced status of $P$. hirsutus is dubious. Thus, only the mussel M. galloprovincialis, the gastropod Littorina saxatilis and the crab C. maenas, are known to have established naturalised populations outside of harbours in the Saldanha Bay region. In 2002, Acuña et al. (pers. comm.) recorded the non-native anemone Sagartia ornata within Langebaan Lagoon. There are thus four alien marine species currently found within the Saldanha Bay-Langebaan Lagoon system.

In response to the growing global awareness of the threats posed by invasive species, the International Maritime Organisation (IMO) (a specialised agency of the United Nations), in conjunction with the Global Environment Facility (GEF) and the United Nations Development Programme (UNDP), has set up the Global Ballast Water Management Programme (GloBallast). Incorporated within GloBallast is an initiative to undertake port baseline surveys of active shipping harbours. At present only six demonstration ports have been selected worldwide, with Saldanha Bay being representative of the African continent.

In view of the threat posed by invading species to the WCNP, and the international focus on the status of alien species in this region, the objective of this study is to set a benchmark regarding the status of marine alien species within and surrounding the West Coast National Park. With this in place, it will be possible to resurvey the area in future years and determine whether the existing alien species have spread or increased in density, or whether new invasive species have colonised the area.

\section{Methods}

\section{Mytilus galloprovincialis}

The shoreline of Saldanha Bay and Langebaan Lagoon was divided into 28 areas, each approximately $3 \mathrm{~km}$ in length (Fig. 1). Area 1 (east shore of Marcus Island) and area 10S (Schaapen Island) covered less than $3 \mathrm{~km}$, but due to their distinct nature were sampled as separate areas. Within each of the areas where rocky shores occurred, three rocky shore sites were sampled, and at each of these, triplicate transects were surveyed. Areas of vertical wharf were not sampled. A $0.5 \mathrm{~m}^{2}$ quadrat was rolled up each transect from Mean Low Water of Spring tide (MLWS) to Mean High Water of Spring tide (MHWS) and the cover accounted for by each mussel species estimated and summed in square metres. Three quadrats (one each in the high, mid, and low shore zones), each measuring $0.016 \mathrm{~m}^{2}$, were sampled within areas of $100 \%$ mussel cover along each transect. The various mussel species were separated out and the whole wet mass of individuals of each species weighed separately, using a spring balance. Together the whole wet weight and cover of Mytilus galloprovincialis were used to calculate the biomass present per meter square $\left(\mathrm{m}^{2}\right)$ and per linear meter (m). The total linear distance covered by rocky shore within each $3 \mathrm{~km}$ area was calculated from the South African Navy chart SAN SC 2, or estimated while working in the field if the rocky shore was too small to be shown on the map. Mussel biomass per linear meter, and length of rocky shore within each sector were then used to calculate the total mussel biomass supported in each $3 \mathrm{~km}$ area.

\section{Carcinus maenas}

Within each sampling area in which rocky shore occurred, a five-minute intertidal search was conducted by four researchers, during which rocks were overturned in an effort to locate C. maenas. Crab traps (18.8 1 volume) made of $1.5 \mathrm{~cm}$ mesh were also set at 17 subtidal sites around the perimeter of the bay and mouth of the lagoon (Fig. 1). Six baited traps were set at each site at $6 \mathrm{pm}$ and were retrieved at $10 \mathrm{am}$ the following morning. The trap design was previously tested in an area known to be heavily invaded by C. maenas (Table Bay harbour), and proved to be extremely effective (up to 50 crabs being caught per trap). Twelve subtidal areas within the bay (Fig. 1) were also dredged using a Day dredge dragged for five to ten minutes, in order to detect subtidal populations.

\section{Littorina saxatilis}

The same basic sampling procedure applied to $M$. galloprovincialis was used to determine the density of $L$. saxatilis within the survey area. In each of the 


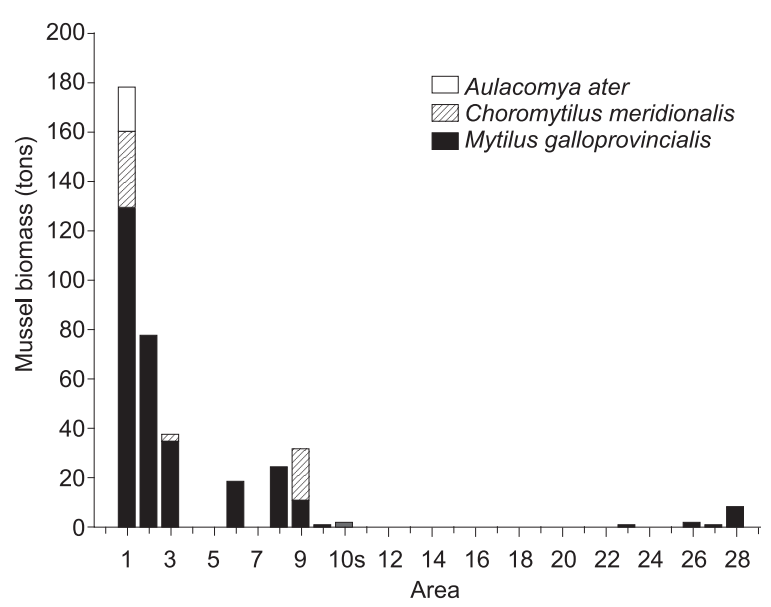

Fig. 2. Total biomass supported by Mytlius galloprovincialis in each sampling area.

$3 \mathrm{~km}$ sampling areas containing beds of Spartina maritima (the known habitat of L. saxatilis), three sites were visited. At each site three transects were layed between MLWS and MHWS. Counts were done within a $0.5 \mathrm{~m}^{2}$ quadrat to determine the number of $L$. saxatilis individuals per $\mathrm{m}^{2}$ and per linear meter of S. maritima bed. The total length of S. maritima bed in each $3 \mathrm{~km}$ sampling area was then used to calculate the total density of $L$. saxatilis.

\section{Sagartia ornata}

Within each $3 \mathrm{~km}$ sampling area, all sites offering suitable habitat (i.e. S. maritima beds or sandy shores with shallow underlying rock) were surveyed for S. ornata. At each site where $S$. ornata was detected, at least two transects were run from MLWS to MHWS. By rolling a $0.5 \mathrm{~m}^{2}$ quadrat up each transect, the number of $S$. ornata individuals per $\mathrm{m}^{2}$ in the high, mid and low shore were determined, as were the number of individuals per linear meter. The length of suitable habitat in each $3 \mathrm{~km}$ sector was then used to calculate overall density of S. ornata.

\section{Results}

\section{Mytilus galloprovincialis}

Mytilus galloprovincialis was found to be widely distributed across all areas of poten- tial habitat within Saldanha Bay and Langebaan Lagoon. This species was recorded in sampling areas 1-9 in Saldanha Bay, was absent throughout most of the lagoon, then reoccurred on the south side of the entrance to the bay. M. galloprovincialis was present in 11 of the 14 sampling areas $(79 \%)$ that had rocky shores. The indigenous mussels Choromytilus meridionalis and Aulacomya ater were recorded in only three and four sampling areas respectively (Fig. 2).

Total standing stocks of M. galloprovincialis per $3 \mathrm{~km}$ sampling area are shown in Fig. 2. Although occurring through out the intertidal, the biomass of this species was centered in the mid-shore. The highest biomass of $M$. galloprovincialis $\left(25.4 \pm 18.7(\mathrm{SD}) \mathrm{kg} / \mathrm{m}^{2}\right)$ was recorded in the mid-shore on Marcus Island, followed by the mid shore of sample area 3 (23.9 \pm 77 (SD) $\mathrm{kg} / \mathrm{m}^{2}$ ). Significant biomasses of 8.3-18.7 \pm 4.7 (SD) $\mathrm{kg} / \mathrm{m}^{2}$ were also supported in the mid shore of sampling areas 6,8 and 9 . Although $M$. galloprovincialis was detected within Langebaan Lagoon (sampling area 23 ), and on the relatively sheltered south side of the bay (sampling areas 26, 27 and 28 ), only a few scattered individuals were present here, representing minimal biomass $(0.01 \pm 0.23,0.06 \pm 0.21,0.26 \pm 0.1$ (SD) $\mathrm{kg} / \mathrm{m}^{2}$ respectively).

Mytilus galloprovincialis had a total intertidal biomass of 281.6 tons within the Saldanha Bay-Langebaan Lagoon system (Table 1). This constituted $79.7 \%$ of the total 353.2 tons of intertidal mussels within the system.

\section{Carcinus maenas}

No live $C$. maenas were recorded in any of the rocky shore sampling areas, despite the fact that many of the sample sites contained what appeared to be ideal habitat. Areas 22-28 in particular offered protected rocky 


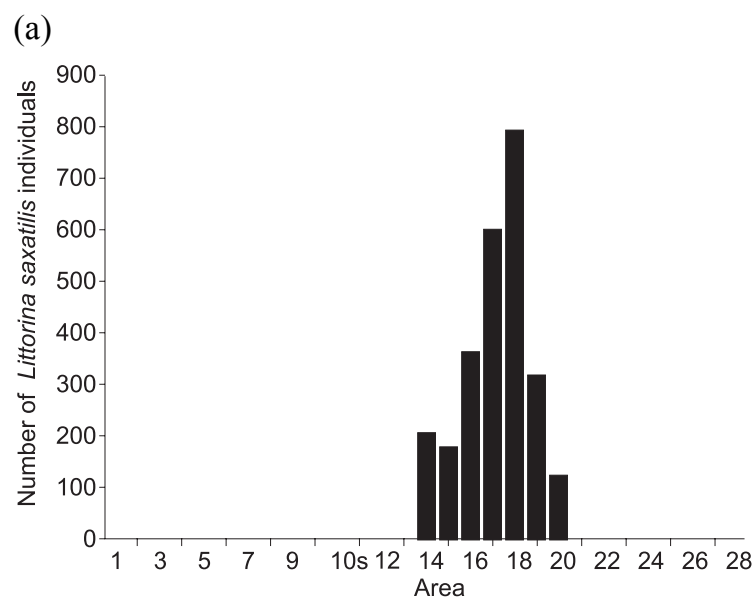

(b)

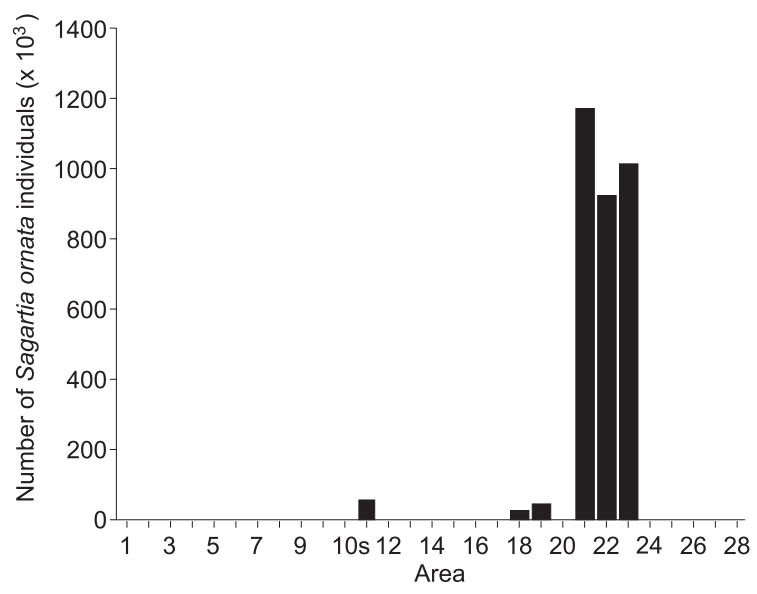

Fig. 3. Total number of individuals of (a) Littorina saxatilis and (b) Sagartia ornata recorded in each sampling area. shores with boulders and numerous potential food species for C. maenas. A single carapace measuring $3.5 \mathrm{~cm}$ was, however, found in sampling area 3 . No C. maenas individuals were recorded during trapping, although the crab Plagusia chabrus, and the whelks Burnupena cincta and Nassarius vinctus were common in the traps. No subtidal populations of $C$. maenas were recorded at sites that were dredged.

\section{Littorina saxatilis}

The periwinkle $L$. saxatilis was only recorded in areas 14-20 (Fig. 3), and was restricted to $S$. maritima beds in the high shore zone. Area 19 supported the highest average densities at $433 \pm 123$ (SD) individuals $/ \mathrm{m}^{2}$. However, as this area supported few Spartina mariti$m a$ beds, the overall density of $L$. saxatilis was much lower than in areas 19 and 20 which support vast beds of S. maritima. A total population of 2.4 million individuals was estimated to occur within the park.

\section{Sagartia ornata}

Very high numbers of the anemone $S$. ornata were recorded throughout the intertidal zone in areas $21-23$,

Table 1

Total rocky intertidal wet biomass (tons) of Mytilus galloprovincialis, Choromytilus meridionalis and Aulacomya ater within Saldanha Bay and Langebaan Lagoon. The percentage contribution made by each species to the total mussel biomass of the system is given

\begin{tabular}{lcc}
\hline & Biomass (tons) & \% Contribution \\
\hline Mytilus galloprovincialis & 281.6 & 9.7 \\
Choromytilus meridionalis & 52.5 & 14.9 \\
Aulacomya ater & 19.1 & 5.4 \\
\hline Total & 353.2 & \\
\hline
\end{tabular}


with highest number occurring in the midshore zone. The highest densities were recoded in the mid-shore of area 21 and peaked at $426 \pm 81(\mathrm{SD})$ individuals $/ \mathrm{m}^{2}$. Much lower densities were recorded in areas 11, 18 and 19. Despite limited suitable habitat being found in areas 13 and 14, no S. ornata were recorded here (Fig. 3).

\section{Discussion}

\section{Mytilus galloprovincialis}

Mytilus galloprovincialis was first recorded along the west coast of South Africa in the early 1980s (Grant \& Cherry 1985), but by 1990 had become the dominant intertidal mussel in the area (Van Erkom Schurink \& Griffiths 1990). As with all aggressive invaders, $M$. galloprovincialis possesses several characteristics that enable its rapid and successful spread at the expense of indigenous species. These features include a high resistance to desiccation, high fecundity and high growth rate (Hockey \& Van Erkom Schurink 1992).

Mytilus galloprovincialis has a widespread distribution across the rocky shores of the area. Being filter feeders, mussels tend to achieve maximal biomass, growth and condition in areas of moderately high wave action (Steffani \& Branch 2003). Thus we would expect $M$. galloprovincialis to achieve maximal biomass within the wave-exposed bay, and lower biomass within the sheltered lagoon. This was generally the case, with mussel biomass being low in sheltered areas along the west side of the lagoon (areas 23-28), and high opposite the mouth of the bay (areas 6,8 and 9). By far the highest mussel biomass, in particular of $M$. galloprovincialis, was recorded on Marcus Island (Fig. 2). The low biomass within Langebaan Lagoon itself, i.e. sampling areas 11-23, can be related to both the low wave exposure experienced in this region and the depleted nutrient supply. Shannon \& Stander (1977) found chlorophyll concentrations within the lagoon to be significantly lower than in Saldanha Bay. This is a consequence of the low rate of water interchange between the bay and Lagoon (Shannon \& Stander 1977), coupled with the uptake of nutrients by macrophytes. The low wave action and turbulence experienced along these shores compound the above, resulting in the low mussel biomass $/ \mathrm{m}^{2}$ observed (Fig. 3).

Although M. galloprovincialis had a large overall biomass of 281.6 tons within the rocky intertidal zone of Saldanha Bay and Langebaan Lagoon, these shores have not always been the only ones to support populations. In the mid 1990s M. galloprovincialis established beds on the sand flats of the center banks of Langebaan Lagoon. These supported a biomass of 77.64 tons by 1998 (Robinson \& Griffiths 2002). These beds, however, underwent a dramatic reduction during 2000 and 2001 (Hanekom \& Nel 2002), and by April 2003 had completely disappeared (Griffiths pers. obs.). Thus, for the purpose of calculating the present total intertidal mussel biomass of the system, only rocky shore populations have been taken into account. In addition to intertidal stocks, the Saldanha Bay-Langebaan Lagoon supports a highly productive mussel culture industry (Fig. 1), where M. galloprovincialis is grown from ropes strung from rafts. The area supports 60 rafts with an average of 332 ropes per raft (Grant et al. 1998). Using the biomass per rope given by Grant et al. (1998), the total biomass of cultured mussels varies between 4080 tons in summer and 677 tons in winter. Consequently, the overall biomass of M. galloprovincialis within the Saldanha Bay-Langebaan Lagoon system is estimated to range between 4362 tons in summer and 959 tons in winter.

\section{Carcinus maenas}

Carcinus maenas was first detected along the South African coast in 1983, within Table Bay harbour (Joska \& Branch 1986). By 1984, this globally recognised invader (Welch 1968; Zeildler 1978; Yamada 2001) had established breeding populations both in Table Bay and Bloubergstrand. By 1990, it had been recorded at eight sites along the 
west coast, including Saldanha Bay (Le Roux et al. 1990). The record from Saldanha Bay was of a single mating pair found in the dam next to the iron ore loading jetty (sample area 6). The European shore-crab is well known predator of molluscs (Welch 1968; Hughes 1979) and has caused dramatic declines in mollusc populations in other parts of the world (Yamada 2001). To date, no such effects have been recorded in South Africa, but this may be due to lack of research. In South Africa, the factor limiting the spread of $C$. maenas is a paucity of suitable sheltered habitat (Yamada 2001). As $C$. maenas is restricted to wave-protected habitats along the South African coast, Le Roux et al. (1990) predicted that the detrimental impacts the $C$. maenas invasion would be most strongly felt in sheltered areas such as harbours, bays and lagoons. Thus the WCNP is particularly at risk.

Although two $C$. maenas individuals were recorded in Saldanha Bay in 1990 (Le Roux et al. 1990), no live individuals have subsequently been recorded (despite extensive sampling throughout the area during annual University of Cape Town student camps). No live animals were captured during the directed trapping operations carried out in this study either. Due to the vigour with which $C$. maenas has invaded other areas and the high level of shipping traffic passing through Saldanha Bay, the total absence of live individuals was unexpected. The occurrence of a single carapace is also curious. One possibility is that a population exists at such low densities that no live individuals could be found. This would be surprising considering that at least some individuals were present 11 years previously.

\section{Littorina saxatilis}

This small intertidal periwinkle was first recorded in South Africa in 1974 (Day 1974). The only known South African populations are in the Langebaan and Knysna lagoons (Hughes 1979), although the present status of the Knysna population is unknown. On the South African coast this species is restricted to sheltered salt marshes and lagoons, where it occurs on the stems of the cord grass Spartina maritima (Hughes 1979), although in its home range it occurs in crevices on rocky shores (Gibson et al. 2001).

Despite establishing dense local populations, L. saxatilis is geographically restricted within the WCNP (Fig. 3), and has not spread dramatically in the more than 20 years that it has colonized this area. No ecological effects of the invasion are known, although this species could form an abundant food source for predators such as wading birds and crabs.

\section{Sagartia ornata}

This anemone is widely distributed throughout western Europe, Britain and the Mediterranean (Manuel 1981), and was first recorded in South Africa in 2002 (Acuña et al. in press). This record was the first in the southern hemisphere. At present, the species appears to be restricted to Langebaan Lagoon, where it occurs intertidally in $S$. maritima beds and on rocks covered by sand. Along British coasts Sagartia ornata is, however, known to occur in crevices on rocky shores and on kelp holdfasts (Gibson et al. 2001). As such, there is potential for this species to spread widely along the South African west coast, which offers cold waters and vast kelp beds which typify its home range. It is thought that this species was unintentionally introduced into the bay via shipping.

The distribution of $S$. ornata within the WCNP is presently restricted (Fig. 3). However, follow-up surveys are needed to ascertain whether it is still spreading within the park, or whether populations have stabilised. The presence of a total of 3.1 million individuals within the WCNP is cause for concern. The ecological impacts of this invasion are likely to be restricted to local effects on small invertebrate prey species. 


\section{Conclusions}

Mytilus galloprovincialis has a wide distribution within the Saldanha Bay-Langebaan Lagoon system, but densities are low within the WCNP itself. It is thought that the invasion of the WCNP and surrounding areas by M. galloprovincialis has reached saturation, and that the biomass supported within the intertidal zone will not increase significantly. Although no live individuals of Carcinus maenas were recorded during this study, the potential threat posed by this crab to the natural biota of the WCNP is of considerable concern and the failure of this species to become established remains a paradox. Littorina saxatilis has not spread significantly since it was first recorded in Langebaan Lagoon in the late 1970s and, due to its benign habits, poses little threat to indigenous biota. Due to the paucity of attachment surfaces it is unlikely that Sagartia ornata will extend its range within the lagoon. However, suitable habitat within Saldanha Bay and along the adjoining coast may see the spread of this species, although it is felt that strong wave action in this region may moderate this range extension. It is interesting to note that although the Saldanha Bay-Langebaan Lagoon system hosts more alien marine species than any other site along the South African coast, the number is still substantially lower than similar international sites such as San Francisco Bay (Carlton et al. 1990).

In order to ensure the future protection of the natural fauna of the WCNP against the threat of invasive alien marine species, conservation authorities need to be proactive. Many developed countries, such as Australia and the United States of America, employ a preemptive approach to marine invasions. In these systems conservation officials are equipped with a list and full description of invasive species which could potentially invade the area. This list includes known global invaders and problem species which are known to occur in similar areas elsewhere. Together with routine surveys, this approach has allowed early detection of a number of invasions. This is important, as it is only in the early stages of marine invasions that removal is a viable management option (Bax 2000). It is thus suggested that a booklet of known and potential marine invasive species be compiled for the South African coast, and that this be made available to South African National Parks officials in marine parks. In addition, periodic surveys such as the one done in this study should be undertaken to monitor the spread and population densities of established invaders.

\section{References}

BAX, N. 2000. Control options. Pp. 248-256. In: Preston, G., G. Brown \& E. VAN WyK (eds.). Best management practices for preventing and controlling invasive alien species. Cape Town: The Working for Water Programme.

Berman, J., Harris, L., LAmbert, W., M. Buttrick, \& M. Dufresne. 1992. Recent invasions of the Gulf of Maine: Three contrasting ecological histories. Conservation Biology 6: 435-441.

Carlton, J.T. 1985. Transoceanic and interoceanic dispersal of coastal marine organisms: the biology of ballast water. Oceanography and Marine Biology Annual Review 23:313-371.

CARLton, J.T. 1996. Marine bioinvasions: The alteration of marine ecosystems by nonindigenous species. Oceanography 9: 36-43.

Carlton, J.T., Thompson, J.K., L.E. Schemel, \& F.H. Nichols. 1990. Remarkable invasion of San Francisco Bay (California, USA) by the Asian clam Potamocorbula amurensis. I. Introduction and dispersal. Marine Ecology Progress Series 66: 81-94.

DAY, J.H. 1959. The biology of Langebaan Lagoon: A study of the effect of shelter from wave action. Transactions of the Royal Society of South Africa 26: 475-545.

DAY, J.H. 1974. A guide to the marine life on South African shores. Cape Town: A.A. Balkema.

Gibson, R., B. Hextall \& A. Rogers. 2001. Photographic guide to the sea and shore life of Britain and north-west Europe. New York: Oxford University Press.

Grant, W.S. \& M.I. Cherry. 1985. Mytilus galloprovincialis Lmk. in southern Africa. Journal of Experimental Marine Biology and Ecology 90: 179-191.

Grant, J., Stenton-Dozey, J., Monteiro, P.M.S., G. Pitcher \& K. Heasman. 1998. Shellfish culture in the Benguela system: a carbon budget of Saldanha Bay for raft culture of Mytilus gallo- 
provincialis. Journal of Shellfish Research 17: 41-49.

GRIFFITHS, C.L. 2000. Overview on current problems and future risks. Pp: 235-240. In: Preston, G., G. BROWN \& E. VAN WYK (eds.). Best Management Practices for Preventing and Controlling Invasive Alien Species. Cape Town: The Working for Water Programme.

Griffiths, C.L., Hockey, P.A.R., C. VAN ERKOM SCHURINK \& P.J. LE RouX. 1992. Marine invasive aliens on South African shores: implications for community structure and trophic functioning. South African Journal of Marine Science 12: 713-722.

Grosholz, E.D. \& G.M. RuIz. 1996. Predicting the impact of introduced marine species: lessons from the multiple invasions of the European green crab Carcinus maenas. Biological Conservation 78: 59-66.

HANEKOM, N. \& P. NeL. 2002. Invasion of sandflats in Langebaan Lagoon, South Africa, by the alien mussel Mytilus galloprovincialis: size, composition and decline of the populations. African Zoology 37: 197-208.

Hockey, P.A.R. \& C. VAN ERKOM SchurinK. 1992. The invasive biology of the mussel Mytilus galloprovincialis on the southern African coast. Transactions of the Royal Society of South Africa 48: 123-139.

HugHes, R.N. 1979. South African populations of Littorina rudis. Zoological Journal of the Linnean Society 65: 119-126.

JoSKA, M.A.P. \& G.M. BRANCH. 1986. The European shore-crab-Another alien invader? African Wildlife 40(2): 63-65.

Le Roux, P.J., G.M. Branch \& M.A.P. JoskA. 1990. On the distribution, diet and possible impact of the invasive European shore crab Carcinus maenas (L.) along the South African Coast. South African Journal of Marine Science 9: 85-93.

Mack, R.N., Simberloff, D., Lonsdale, W.M., Evans, H., M. Clout \& F.A. Bazzaz. 2000. Biotic invasions: causes, epidemiology, global consequences, and control. Ecological Applications 10: 689-710.
Manuel, R.L. 1981. British Anthozoa. London: Linnean Society

Minchin, D. 1996. Management of the introduction and transfer of marine mollusks. Aquatic Conservation of Marine and Freshwater Ecosysteyms 6: 229-244.

RoBInSON, T.B. \& C.L. GRIFFITHS. 2002. Invasion of Langebaan Lagoon, South Africa, by Mytilus galloprovincialis-effects on natural communities. African Zoology 37: 151-158.

Shannon, L.V. \& G.H. Stander. 1977. Physical and chemical characteristics of water in Saldanha Bay and Langebaan Lagoon. Transactions of the Royal Society of South Africa 42 (3 \&4): 441-459.

StefFAni, C.N. \& G.M. BRANCH. 2003. Growth rate, condition, and shell shape of $M$. galloprovincialis: responses to wave exposure. Marine Ecological Progress Series 246: 197-209.

SuMMERS, R.W. 1977. Distribution, abundance and energy relationships of waders (Aves: Charadrii) at Langebaan Lagoon. Transactions of the Royal Society of South Africa 42: 483-494.

Unit For MARINe StUdies. 2000. South Africa's maritime industries. Cape Town: M.E.R.I.T

VAn Erkom Schurink, C. \& C.L. Griffiths. 1990. Marine mussels of southern Africa - their distribution patterns, standing stocks, exploitation and culture. Journal of Shellfish Research 9: 75-85.

Welch, W.R. 1968. Changes in abundance of the green shore crab, Carcinus maenas (L.), in relation to recent temperature changes. Fishery Bulletin 67 (2): 337-345.

Williams, R.J., Griffiths, F.B., E.J. VAN Der WAL \& J. KeLLY. 1988. Cargo vessel ballast water as a vector for the transport of non-indigenous marine species. Estuarine, Coastal and Shelf Science 26: 409-420.

YAmadA, S.B. 2001. Global invader: the European green crab. Oregon: Corvallis.

ZEIDlER, W. 1978. Note on the occurrence of the European shore crab Carcinus maenas (Linn., 1758) in Australia. South Australian Naturalist 53 (1): 11-12. 